\title{
Tricks of the trade or situated literacy - disciplinary reading literacy practices in vocational education
}

\author{
Pia Visén \\ Department of language education, Stockholm University
}

\begin{abstract}
In upper secondary school vocational education in Sweden practices of reading is an integrated part of teaching in vocational subjects. This study aims to gain a deeper understanding of vocational reading literacy practices, and how reading literacy practices are recontextualised into upper secondary school contexts. Three subsequent research questions specify the study: What kinds of texts are used? How is reading done and talked about? What purposes for reading (why) emerge? Theoretically, the study draws from New Literacy Studies (Barton, 2007). Nine vocational teachers were interviewed regarding reading in childcare, technical, culinary, and industrial vocations. The informants were also observed when teaching in four student groups in three upper secondary schools. Analyses were made of text categories, genres (Rose \& Martin, 2012), reading literacy events, text movability (Hallesson \& Visén, 2018; Liberg et al., 2012), and reading types (cf. Rosenblatt, 1995). The results reveal a wide range of text categories, from general to specialised texts, specific practice-oriented reading events, reading types that differ depending on vocational context. A conclusion is that disciplinary reading practices in vocational contexts are complex and require critical readers. Therefore, further knowledge of reading in vocational education might contribute to the teaching of disciplinary reading literacy in upper secondary vocational education.
\end{abstract}

Keywords: reading; disciplinary literacy; vocational education; upper secondary school

Received: May, 2020; Accepted: February, 2021; Published: April, 2021

\section{Introduction}

Practices of reading and writing have increased immensely and the demand for reading literacy is increasing across professions (Janks, 2010; Karlsson, 2009, 2012). This has called for a deeper knowledge of reading literacies and how schools can work with reading literacy across subjects and programmes (e.g. Moje, 2007, 2008; Shanahan \& Shanahan, 2008, 2012).

\footnotetext{
^Correspondence: Pia Visén, email: pia.visen@isd.su.se
} 
The present study was conducted in Sweden. In Sweden, 12 out of 18 national upper secondary school programmes are vocational programmes. ${ }^{1}$ Approximately one third of Swedish upper secondary students are enrolled in vocational programmes. In $2019,37,2 \%$ of applications to upper secondary school were applications for vocational programmes and 62,8\% applications for higher education preparatory programmes (Skolverket, 2020). Both vocational and higher education preparatory programmes are three years and contain 2500 upper secondary school credits. In vocational programmes 600 credits come from subjects common to all secondary school programmes, like history, maths and Swedish. Remaining credits, 1900, are from programme specific school subjects. Vocational students also do 15 weeks of workplace-based learning over the three years in the programme. Upper secondary school vocational programmes lead directly to a vocational exam. In all vocational programmes students can choose to take extra subject courses in e.g. Swedish and maths, so as to qualify for tertiary education as well as receiving a vocational exam. High drop-out rates and vocational students' not passing programme specific subjects have been noted, whereas general subjects such as Swedish and maths are passed to a larger extent (cf. Skolinspektionen, 2013). A suggested possible reason for the high drop-out rates is specific and complex literacy demands (cf. Skolinspektionen, 2013). In spite of this, practices forming reading literacy in vocational areas and subjects is largely a field that remains to be investigated. The languages and literacies of subjects such as history and science on the other hand, have been studied by for instance Schleppegrell (2004), and reading literacies in the disciplines of maths, chemistry, and history by Shanahan and Shanahan (2008, 2012).

Research shows that disciplinary reading literacy practices have specific features (Shanahan \& Shanahan, 2008). Historians interpret meaning through the lens of the author's perspective, while chemists consider the author as a quality screen when choosing text (ibid.). Chemists go back and forth between the texts' different representations to encompass meaning (ibid.). Shanahan and Shanahan argue that disciplinary literacy is the literacy of the expert, and in relation to the progressing complexity of the literacy skills needed as the specialisation of subjects and texts increases through school, the need for disciplinary literacy teaching increases (2008, 2012). In the same way, it can be assumed that the disciplinary reading literacies of vocational areas are specific and that the teaching, therefore, requires specific insights (cf. e.g. Buch, 2015, 2020; Darvin, 2004; Kabel et al., 2009).

This article presents a study of reading literacy practices in vocational contexts and in vocational education contexts, aiming to contribute to the knowledge in this field.

\footnotetext{
${ }^{1}$ As well as national vocational programmes, the upper secondary school system also includes apprenticeship programmes. Apprenticeship programmes are also three years and contain some school subjects, but in an apprenticeship programme 1250 out of the 2500 credits are apprenticeship in a work place.
} 


\section{Previous research}

Disciplinary literacy can be described as a triangle relating practices of academy, workplace, and society (Airey, 2011). Different disciplines, located at some point within the triangle, emphasise different aspects of literacy. Disciplinary literacies can be regarded as forms of literacy functional in specialised settings. Among engineers and in academic engineering education e.g., lists are part of central literacy practices for structuring and communicating information and instructions (Hållsten, 2008). The active participants are the literacy experts, and to develop disciplinary literacy is to develop the ability to participate in the literacy practices (Airey, 2011).

Since texts are seen as tools in the professional sphere, literacy practices are part of the learning of vocational knowledge (cf. Karlsson, 2009, 2012; Lindberg, 2010). Vocational students therefore read texts to accomplish tasks, and they need to learn to use the texts in relation to the task at hand (Lindberg, 2010).

Danielsson and Selander (2014) analyse school texts, including a multimodal text for the subject of welding in the Industrial Technology programme. They show how images tend to illustrate the verbal text, and also that the text is highly theoretical despite its practical aim (Danielsson \& Selander, 2014). Further, that the welding text uses a linguistic style which resembles natural science discourse due to the use of specific terminology as well as grammatical metaphor (ibid.). The complexity of texts used in vocational programmes is highlighted by Buch (2020) in systemic-functional analyses. Buch (2020) argues that stronger literacy skills can support vocational students' meaning-making when reading but also their position in society. Buch (2015) finds three macrogenres of texts in vocational teaching: texts regulating teaching, texts constructed by teachers and specialised texts. The specialised texts depend highly on terminology, and teacher talk therefore functions as a mediating tool for students' meaning-making (Buch, 2015). Further, a Danish study shows that the readability of a text book in bricklaying is complicated by technical vocabulary, complex syntax, passive clauses and nominalisations, and that the complexity of the text required the teacher to guide the students in the use of the text (Kabel et al., 2009).

Vocational texts position their readers in certain literacy roles, as someone recontextualising and transferring knowledge, as someone awaiting orders, or as a commited partner (Karlsson, 2009). Being able to enter several different literacy roles may therefore be key to flexibility and successful problem solving (Karlsson, 2009). Another way of putting this is that the text contains expectations on its reader, i.e. is written for a model reader. Lilja Waltå (2016) studied textbooks in the subject of Swedish for upper secondary vocational programmes and identified how expectations for reading achievement, processing, and analysing both literary and non-fictional texts constructed a presumed vocational model reader that is uncritical, seeking factual knowledge, escaping the deeper meanings of the texts.

However, a large-scale ethnographic study of different trades in Britain shows varied and complex uses of writing (Ivanić et al., 2009). Hellne-Halvorsen also found 
that vocational teachers use literacy practices as mediating tools to build students' disciplinary knowledge: writing to store knowledge, reflect, or to assess practical tasks (2014). Westman (2009), studying writing practices in Swedish upper secondary vocational education, found practices involving note-taking, answering questions, and writing work reports. Meanwhile, reading practices appeared to be more prevalent than writing (Westman, 2009).

Interview studies of vocational tutors in carpentry and automotive technology, as well as analyses of textbooks and student writing, show how literacy practices are dominated by reading practices where a wide variety of texts are read, comprising complex literate demands (Parkinson \& Mackay, 2016). Nevertheless, vocational students experience difficulties when meeting the reading practices of the workplace in their workplace-based learning and use strategies like asking for help rather than reading independently (Olofsson, 2011). This indicates a gap between the reading taught in school and the reading expected in the workplace (cf. Karlsson, 2009). However, difficulties caused e.g. by the complexity of vocational texts were addressed in a New Zealand action research project where aspects of literacy methodology were introduced, which improved vocational learning and teaching (Schwenger, 2018).

Meanwhile, vocational educators in Culinary arts, Equestrian, and Health care programmes in a New York vocational school used a plethora of texts and efficient ways of reading were applied for specific purposes (Darvin, 2004, 2006). The texts were read to accomplish particular goals and to gain specific information. The texts were often not read in linear, sequential patterns but rather in: "bits and pieces to solve problems, research and enhance particular stages of the projects in which they are engaged" (Darvin, 2006, p. 12). Darvin shows that literacy practices in vocational education are aligned with literacy practices in the workplace. However, the vocational teachers do not see their work with literacy as reading:

The culinary instructor did not define a good reader as someone who can read and follow a recipe accurately. The auto mechanic did not define a highly literate person as someone who can decipher a diagram or schematic properly. They see those abilities as being "tricks of the trade," whereas reading and literacy are still seen as school-related or academic only. (Darvin, 2006, p. 16)

Ideas of vocational work with texts as not being reading might shape work with reading in vocational education. Therefore, further knowledge of what disciplinary reading literacy in vocational education can be may contribute to developing both more critical perceptions of reading, as well as ways of teaching vocational disciplinary literacies. Against this background, researching vocational disciplinary reading literacies both outside and within educational contexts is of interest in the work to develop knowledge about disciplinary literacies.

In spite of an increasing research interest in vocational literacy, there is a lack of research that investigates what vocational reading literacy entails and what aspects of vocational reading literacy that are taught and acted out in vocational education. This article is trying fill this gap by an investigation of vocational disciplinary reading 
literacy practices in relation to vocational disciplinary reading literacy practices in upper secondary school.

\section{Aim and research question}

Thus, the aim of this study is to give an overview of vocational disciplinary reading literacy practices as expressed by vocational literacy experts, ${ }^{2}$ and of the recontextualisation of vocational disciplinary reading literacy practices in Swedish upper secondary school. The overriding research question in this study is:

- How are vocational disciplinary reading literacy practices recontextualised into upper secondary school contexts?

The subsequent research questions are:

What kinds of texts are used?

- How is reading done, as well as talked about?

- What purposes for reading emerge? (Why)

The questions are answered by analysing the material in two steps,

- first, the what, how, and why of the vocational literacy experts' reading practices are analysed,

- second, the what, how, and why of the reading practices in upper secondary school are analysed.

\section{Method and material}

The empirical material for this study consists of observations, texts, and interviews. The material was collected in three upper secondary schools in municipalities in different regions of Sweden. Ethical considerations were observed in line with the principles of the Swedish Research Council (2017).

Nine informants, teaching in four different upper secondary vocational programmes, were observed in their role as vocational teachers and interviewed in their role as vocational literacy experts in different areas: three informants from Child and Recreation (CR), two informants from Industrial Technology (InT), two informants from Vehicle and Transport (VT), and two informants from Restaurant Management and Food (RF). 62 students participated in the observations: 21 CR, 17 InT, 13 VT, $11 \mathrm{RF}$. The programmes were chosen to represent a variety of upper secondary school vocational programmes. For instance, gender was considered in that two of the programmes, CR and RF, usually have mainly female students and two, InT and VT, usually attract mainly male students. Recruitment was considered including a width of vocations to include aspects of care, construction, design, creativity and repairs.

\footnotetext{
${ }^{2}$ The vocational literacy experts in this study are nine vocational teachers with vocational training and long previous and present professional experience in different vocations. See section on method and material for further specification.
} 
Observations of teaching and learning activities were conducted in classrooms and school workshops or kitchens through the course of one year, for five to six days of teaching in one student group in each programme. The observed lesson time amounts to a total of 60 hours. The observations were documented by video and audio recordings, field notes and photos. Segments relevant for analyses were transcribed. Informal interviews were done with the VT students. ${ }^{3}$ The observations serve to give insight into the situated pedagogically recontextualised vocational disciplinary reading literacy practices as acted out in upper secondary school contexts.

The observed subjects are:

- CR: special education, leadership, nature guiding, children's development

- InT: materials studies, welding, carpentry, design, CAD/computer aided design

- VT: cars - repair and systems technology, vehicle branch conditions

- RF: foods and nourishment studies, restaurant and foods branch conditions

The texts that were collected consist of the educational and vocational texts that were observed being read in the vocational classes. The texts were collected either by photographing them or as text copies. The texts consist of vocational course books, vocational texts, digital textmaterial and text copies. ${ }^{4}$

After the observations, semi-structured literacy history interviews (cf. Lillis, 2008) were conducted with the teachers based on an interview guide presented in Figure 1:

Give examples of texts you read in your vocation and to develop your professional knowledge:

How do you:

- Choose the text -

- Read the text -

- Work with the text -

Compare this with how you plan for reading in your school subject:

Figure 1. Interview guide

The interview guide was handed out approximately two weeks before the interviews in order to give the informants preparation time. It was stressed that focus was on

\footnotetext{
${ }^{3}$ The interviews with VT-students were conducted spontaneously regarding the practice of reading fiction which was revealed as an activity recurring daily in the subject cars - repair and systems technology. The interviews complement the observations and teacher interviews. The students were asked what they read and have read during their three years as well as how they view reading. The practice of including the reading of fiction as part of the disciplinary reading practice was unique to VT and therefore I saw the student interviews as valuable complementary material to deepen my understanding of the practice, even though there is no corresponding material from the other student groups.

${ }^{4}$ The results section of this article report both the text material collected during the observations of the educational context and also report the texts that the interviewees describe in the interviews.
} 
reading literacy practices in the respective vocations as chef, welder or car mechanic, etc. Each interview lasted for approximately one hour. The total interview time is 12 hours. The interviews were video-recorded and transcribed. The interviewees have vocational education and experience, both in the past and presently, and are thus participants in the respective vocational literacy practices. They are, therefore, considered reading literacy experts in their respective vocations. All nine work as vocational teachers in the observed groups. Six of them are certified vocational teachers. Table 1 describes the interviewees.

Table 1. The interviewees

\begin{tabular}{ll}
\hline Program & The interviewees \\
\hline (CR) & T1: Instructional assistant, Recreation leader, Certified teacher \\
& T2: Special education pedagogue, Recreational pedagogue, Certified teacher \\
& T3: Pre-school teacher, Certified teacher \\
(InT) & T4: Joiner, Designer, Special design carpenter \\
& T5: Welder \\
(VT) & T6: Machine engineer, Excavator operator, Certified teacher \\
& T7: Car mechanic, Certified teacher \\
(RF) & T8: Chef, Certified teacher \\
& T9: Chef \\
\hline
\end{tabular}

The interviews serve to give insights into situated vocational reading literacy practices. The implications of literacy history interviews is that the result relies on what the informants say about what, how and why they read which may differ from actual practices. However, interviews give the researcher opportunities to catch sociocultural features, attitudes, and develop statements the informants make. On the one hand, follow-up questions in a semi-structured interview may risk the informant being guided to give expected answers. On the other hand it may lead to precise and developed insights.

The methodology thus is mainly ethnographically inspired, drawing from linguistic ethnography (cf. e.g. Lillis, 2008). In this study observations and interviews serve to complement each other. Where observations can show situated literacy practices in teaching and learning, interviews can describe literacy practices of an experienced vocational expert, i.e. a literacy to aim at in vocational education. However, in the analyses, a number of theoretical concepts serve to deepen the understanding of the reading literacy practices.

\section{Theoretical underpinnings and analytical frame}

A backdrop for the study is a view of learning as dependent on social interaction, partaking and socialisation (e.g. Säljö, 2000), as well as a functional perspective on language (Halliday, 2014). 
Drawing from New Literacy Studies, literacy is regarded as situated social practices rather than acquired skills (Barton, 2007). Literacy events, activities, take place within literacy practices constructed by recurring activities, ideologies, and attitudes (Barton, 2007). The idea of literacy as situated informs the research field of disciplinary literacy where academic and professional disciplines are studied as situated literacy practices (cf. Shanahan \& Shanahan, 2008, 2012).

To answer the questions in the present study, an analytical frame was constructed holding the following theoretical aspects:

To answer what is read within the literacy practices the collected texts were surveyed regarding categories and analysed regarding genres following the definition of genre as staged goal-oriented processes (Martin \& Rose, 2008). Examples of genres and stages are:

- Description: 1) classification 2) descriptions

- Explanation: 1) phenomenon 2) different kinds of explanations (e.g. causal)

- Recount: 1) orientation 2) record of events

- Instruction: 1) goal 2) equipment 3) steps (cf. Rose \& Martin, 2012)

To answer the question of how, two analytical tools were used studying observations and interviews. How the readers act when reading was studied by descriptive analyses of literacy events, categorising activities in reading events such as text choices and text work. Examples of categories are: re-reading, close reading, underlining, non-linear reading. To further answer how, analyses were conducted of text movability, i.e. how the reader by talking about the text moves within and out of the text:

- text-based within the text, e.g. exploring vocabulary, summarising, generalising, or critically examining the content,

- associatively out from the text into experience, knowledge, and other texts, and

- interactively talking about writer and reader roles, or the text as genre or social function (Hallesson \& Visén, 2018; Liberg et al., 2012).

To answer the question of purpose, why, observations and interviews were analysed regarding which reading types that frame text reception. Reading types are made up of ways of understanding and responding to texts, at the same time as the reading type makes the text emerge in a certain way (cf. Tengberg, 2011). Various aspects interplay at setting the reading type, for example, context, focus, and how questions are formed. Reading has been described as being of two basic types, efferent, analytically searching for certain answers, or aesthetic, meeting the text as a work of art (cf. Rosenblatt, 1934/1995).

Non-fiction reading types have been described as: factual individual-oriented, where the text is a tool for personal development, and factual text-oriented, where the text content is studied and used objectively (Josephson \& Melander, 2003). Specific ways of reading in vocational contexts have been identified as, for example: reading to do, to learn, to assess, and to learn to do. (Darvin, 2006; Kakela, 1993). 
In this study the concept of reading types has been operationalised into the following analytical categories:

- Analytical-Technical: learning facts, form, and formal aspects

- Analytical-Practical: following text in order to solve a practical task

- Analytical-Technical-Practical: learning in order to later try out in practice

- Analytical-Assessing: evaluating text for various aspects depending on the context

The analytical terms text movability and reading type both draw from reception theory viewing reading as a meeting between text and reader where transaction, an interpretation of meaning dependent on both text and reader, takes place (e.g. Rosenblatt, 1995).

This analytical frame catches some aspects of the reading literacy practices that facilitate an overview while others, like e.g vocabulary or cohesion, are not investigated.

\section{Results}

This section gives an overview of the overall results, which show a plethora of texts read in several ways, for different purposes, and to give diverse perspectives on the explored issue. Reading is done to solve problems, answer questions, get inspiration, stay updated within the field, build both general and specific knowledge, and for general interest. Re-reading is stressed as an important aspect and pendulum-reading often ties text and task together. When talking about texts, all text movability types emerge; content, structure, connections to previous knowledge, experience and society, author role, genre, etc. are discussed.

In the following four sections, the results of the respective analyses will be presented and related to the four programme contexts. Examples ${ }^{5}$ are taken from transcriptions of interviews and observations and serve to illuminate the analyses.

\section{Texts}

This section presents the result of the study of what texts are read, both as observed and collected in the vocational educational context, as well as what texts the informants report in the literacy history interviews.

A wide range of text categories, both general and specialised, are found in all four vocational orientations. Many of the texts are complex and multimodal using different forms of representation. The genres comprise explanation, description, instruction, recount/narrative and argument (cf. Martin \& Rose, 2008; Rose \& Martin, 2012). Table 2 gives an overview of the range of texts and genres that are either only stated in the interviews or that are both stated in interviews and observed being used

\footnotetext{
${ }^{5}$ Examples are translated from Swedish into English.
} 
in the educational context. Bold posts are texts both reported in the literacy history interviews and also used in the educational context.

Table 2. Overview of text categories and genres

\begin{tabular}{|c|c|}
\hline Programme & Texts, genres \\
\hline (CR) & $\begin{array}{l}\text { research articles, popular science, academic literature, special interest magazines, } \\
\text { newspapers, pedagogic debate articles, news, various internet texts (e.g. articles, } \\
\text { advertisements; encyclopedias), legal documents, biographies, fiction, young adult } \\
\text { fiction, children's literature, vocational subject textbooks. } \\
\text { Genres: narrative, recount, description, explanation, argument }\end{array}$ \\
\hline$(\operatorname{InT})$ & $\begin{array}{l}\text { photos, drawings, design plans, draughts, technical manuals, trade publications, } \\
\text { special interest magazines, internet articles and journals, design history, safety instructions, } \\
\text { time reports, signs, welding procedure specifications, vocational subject textbooks and } \\
\text { digital resources } \\
\text { Genres: recount, description, explanation, instruction }\end{array}$ \\
\hline$(\mathrm{VT})$ & $\begin{array}{l}\text { technical literature, physics literature, popular science articles, research articles, } \\
\text { manuals, digital manuals (in different languages), newspapers, news and other } \\
\text { internet texts, debate articles, trade publications, special interest magazines, schematics, } \\
\text { diagrams, vocational subject textbooks and digital resources, fiction } \\
\text { Genres: recount, description, explanation, argument, instruction, narrative }\end{array}$ \\
\hline$(\mathrm{RF})$ & $\begin{array}{l}\text { recipe-books, meps, }{ }^{6} \text { newspapers, special interest magazines, special interest } \\
\text { non-fiction, legal documents, vocational subject textbooks, debate articles, research } \\
\text { articles and information from the Swedish National Food Administration, popular science } \\
\text { articles, branch information, nutritional value declarations, fiction }\end{array}$ \\
\hline & Genres: recount, description, explanation, argument, instruction, narrative \\
\hline
\end{tabular}

The table shows that within the vocations, as well as in the four programmes, a plethora of texts containing several genres is read. Some of the texts are specific to the vocation, as e.g vocational subject text books, articles from special interest magazines and non-fiction, or research articles within the vocational field. Other texts are more general, and more or less loosely tied to the specific vocation, e.g. newspaper articles or fiction. The variety of text categories and genres are considered part of the vocational reading practice. However, the amount of text categories observed being read in the educational contexts is more limited than what the interviewees claimed to read in their vocational professions. All interviewees e.g. mentioned reading research and new discoveries within the field, while in their observed teaching, they rather rely heavily on textbooks.

\footnotetext{
${ }^{6} \mathrm{Mep}$ is an abbreviation for mis-en-place which is a detailed text the chef (or student) writes when planning work and material. The mep is read in the kitchen as the work proceeds.
} 
Differences regarding text categories are also revealed:

In CR biographies, autobiographies and fiction occur. Learning objectives when these texts were studied were for example group dynamics, leadership, or concepts like professional conduct.

In InT images are used as inspirational texts for designs, as well as histories of designs and designers. Draughts are read as instructions for carpentry and welding projects. Other categories of texts are procedure instructions and procedural recounts, as well as tables and descriptions of materials.

At VT fiction, physics literature with technical-theoretical descriptions, and explanations are read. Schematics and service handbooks are used in practical work. Some texts are in other languages than Swedish.

In $\mathrm{RF}$ recipe-books and meps, as well as inspirational literature and images, are read. Fiction is mentioned in the interviews as inspirational and informative of how human conditions are affected by foods and production. However no reading of fiction is observed.

In summary, a width and variation of text categories are read, both general and specific, ranging from e.g. inspirational texts and newspaper articles to research articles and vocational subject textbooks, as well as vocational texts such as draughts, technical handbooks and recipes. The texts are made up of a variety of genres, such as recount, description, explanation and instruction. The text variety however, is more limited in the observed educational contexts than what is reported in the literacy history interviews.

\section{Reading events}

This section presents the result of the analyses of how reading is acted out. Table 3 gives an overview of reading events the interviewees described regarding the vocational literacy practices and reading events that were observed in the four programmes. Bold posts were found both described in interviews and revealed being acted out in the educational contexts.

Table 3. Reading events

\begin{tabular}{ll}
\hline Program & Reading events \\
\hline (CR) & Text choice originates in a concept or question. Author's reliability is considered: does the text \\
& build on research or just opinion" (T1). \\
& Parallel texts in different genres, going-back-and-forth within and between the texts. \\
& Linear reading \\
& Skimming \\
& Underlining \\
& Note-taking \\
& Re-reading \\
& Summarising \\
& Commenting \\
& Pendulum-reading trying out the text content in reflections \\
& Text-talks with colleagues integrated in the reading
\end{tabular}




\begin{tabular}{ll}
\hline Program & Reading events \\
\hline (InT) & Texts are chosen to give ideas and build knowledge for construction and design, as well as \\
& instructions for the procedure \\
& Linear reading \\
& Deconstructive centrifugal reading: "starting in the middle and exploding the text" (T5) to \\
& reveal how different parts relate to each other \\
& Pendulum-reading using the text content in practice \\
& Check understanding with colleagues. Text-talks \\
& Text choice originates in news and the current debate about new technical development. Texts \\
& are chosen to build knowledge. Author's intention and clarity of text is considered: "I read and \\
& see if the author is explaining clearly [...] and also if they are reliable" (T7) \\
& Linear reading, detailed, reassuring understanding of technical details \\
& Drawing of sketches, schematics \\
Re-reading of central aspects & Pendulum-reading using the text content in practice \\
Check understanding with colleagues. Text-talks \\
Texts are chosen to give creative inspiration and knowledge, looking for what is "serious, \\
to avoid glossy and superficial texts" (T9). Reliability of text and author's intention is \\
considered: "I read a broad spectrum of texts but I sort out what is only advertising" (T8). \\
Parallel texts are read. Going back and forth in the texts \\
Linear reading \\
Note-taking \\
Memorising \\
Re-readings \\
Pendulum-reading using the text content in practice \\
Check understanding with colleagues. Text-talks
\end{tabular}

All the interviewees emphasise the need to be up-to-date with developments within their different fields, and that reading is the means towards that end. They critically choose and read texts to get different perspectives on questions or to solve problems. In their teaching, however, they often hand out texts to the students rather than modelling how to make critical text choices. One exception is when the students in $\mathrm{RF}$ work individually on a task requiring text choices:

T8: $\quad$ "If you need information on chicken, which will be most reliable, the company that produces chicken or the National Food Agency?"

Student: "National Food Agency, the others want to sell, so they might hold back information."

The reading events are collective, students and teachers read together in different constellations. The teachers read most texts aloud and model ways of using texts. Working on a text about materials $\mathrm{T} 4$ models his reading:

T4: "When I read this kind of text, I skim these parts and read these boxes more carefully, also I start with the box and work my way out from it. Let's do it that way." 
When introducing a text, T3 instructs her students to read in a way that has earlier been modelled:

T3: "Let's read this text in the same way as we did the other day."

Collectively discussing texts and clarifying text contents with colleagues is described in the interviews as an integrated part of vocational reading literacy to:

T3: "deepen knowledge and understanding and give new insights."

As well as to:

T5: "make sure you understand."

In all four groups, text-talks is also an integrated part of teaching, socialising the students into discussing texts.

A recurring way of reading is going back and forth between text and practice, using and trying out text content in specific situations. This constitutes a pendulumreading. Pendulum-reading is closely tied to the vocation:

T4: "The understanding of the text needs to be realised in the hands."

Pendulum-reading is observed for example when RF-students work from recipebooks and meps going back and forth between texts and task. Pendulum-reading is also observed when VT-students work with a number of texts comparing them and using them intermittently in the repairs of a car: reading a work order, executing checks, reading handbooks and schematics, trying out a corrective measure, reading another part of the text or another text, trying again, etc. In InT similar pendulum-reading takes place e.g. when the students work on building chairs from draughts and instructions. Pendulum-reading is thus revealed as a vocational reading practice in all four contexts:

T7: "where the result of the work shows how well the text is understood."

The analyses also reveal literacy events that are specific in the respective investigated contexts: In CR, skimming lists of contents, headings, etc. initiates reading literacy events.

Reading in InT may originate in an image, and verbal texts are chosen to add knowledge to that image:

T4: "to complete a picture."

The reading and interpretation of draughts is centrifugal, starting with the central aspect:

T5: $\quad$ "Find the central point, what holds the thing together, and start reading the draught from there. Work outwards from the middle and most important point."

Reading is also deconstructive; the text is deconstructed into parts in order to explore relations between aspects in the text content: 
T4: 'I 'explode' the image the text gives into details, try to understand all the aspects, such as suitable materials, and construct a working procedure out of it, turn the text into my own creation."

Reading is thus a creative three-dimensional process where a mental image is created of a possible process and product.

In VT, texts are chosen to build knowledge that gives the ability to move between current debate in informed critical ways and the hands-on work with repairs and customers. Schematics are drawn to process, understand, and remember. This is a multilingual literacy practice, where texts, especially manuals, often come only in original languages and reading therefore often entails translating.

The teachers at RF choose texts for creative inspiration. They also describe memorising text as a vocational skill:

T6: "It is like I take a photo of the texts in my head."

However, memorising is not modeled to the students.

In summary, reading events contain linear reading, text-talks checking and developing understanding, as well as critical text choices. Recurring in the reading events is pendulum-reading, a continuous moving back and forth between reading and a practical task. However, ways of reading also differ depending on vocational context. The students are socialised into the specific reading literacy events by instructions and modelling. Nevertheless, reading events in the observed teaching contexts seem more limited than what the interviewees describe as vocational reading literacy events.

\section{Text movability}

This section presents the results of the analyses of how texts are talked about. Examples and analyses of text movability in both literacy history interviews and observed in the educational context are presented in the following order, first text-based movability, second associative text movability, third interactive text movability. The analyses reveal text movability of all types and in several dimensions.

\section{Text-based movability}

Text-based movability dominates and is revealed for instance when texts are used for learning terms and concepts that are central to the vocation. Teacher 1 talks about text-based movability in a critical dimension:

T1: "I sort out what is just opinion and what is research result and try to work out what text will teach me something and what text just wants me to think something."

The critical dimension of text-based movability also concerns the practical implications of the text content:

T4: $\quad$ "I need to be able to discern whether the text is correct or full of mistakes otherwise the product might end up any which way." 
Dimensions of text-based movability are shown in the educational literacy practices e.g. when a student in RF comes upon the Swedish word "spad" (stock) in the sentence "Use half of the remaining stock" in a recipe:

Student: “'Spad', what is that? Half the 'spad'? Is that the same as spade? ${ }^{7}$ Does it mean half a spoon?"

T8: "Spad (stock) is a cooking word for the liquid."

Here, reading entails talking about subject and vocation specific vocabulary. In RF text-based movability also includes summarising, interpreting implicit information, as well as critically scrutinising text content:

T8: "When it comes to foods these days you have to be careful when you read. Lots of things are presented as truth, but you need to sort out what is based on real research and what is from a more consumerist source."

At VT text-based movability is revealed e.g. when two students, working on a car, discuss both main content and specific details of the text while executing different tests on the car's computer system. The reading is acted out as pendulum-reading going back and forth between interpreting the text and troubleshooting the car. Here the content of the text is also summarised and critically examined. Another example of text-based movability is when T7 tells one student in VT to infer meaning:

T7: "Here you cannot find the answer on the lines in the text, but have to draw a conclusion."

Text-based movability is shown when comments are made about main content, technical detail, inferences about functions, as well as generalisations, or relationships between mechanical functions, physics, and practice, and, therefore, are read critically for detail-correctness.

At the InT-programme text-based movability is expressed in a number of ways. Texts are explored for main contents:

T4: "for example, to understand how different materials are constructed, or just the history of a designer and his ideas, like Malmsten."

Based on text content generalisations and inferences about constructions, form and function are done. Texts are also critically evaluated for their practical functions:

T5: "I read carefully to see if the draught and descriptions can be correct."

\section{Associative text movability}

Associative text movability draws on earlier knowledge and experiences in the reading. All teachers discuss the necessity of relating text content to work practices in order for texts to make sense. One example of associative text movability being expressed

7 "Spade" translates into spade or shovel in Swedish. 
in the educational context is when students in CR discuss workplace-based learning in relation to a text on professional conduct:

Student: "That is like when we were out in the playground in breaks. We had to work hard to solve conflicts between the children. But some staff were really angry and one of them was unfair."

T3: "Yes, how can you use the term professional conduct from the text to discuss that experience?"

Student: "Professional conduct then would have been to be fair."

At $\mathrm{RF}$ relating the text to earlier theoretical knowledge of nourishment and practical knowledge of processes and procedures contribute associatively in the reading:

T8: "When you have tried out something you see when you read if it will work."

At VT, the teacher encourages the students to make use of experiences of repairing cars when reading a complex text:

T7: "When you read this, try and remember and imagine the work you did yesterday. What did it look like?"

\section{Interactive text movability}

Interactive text movability is expressed for instance when teachers inform students about text category or genre and how the reading should be done:

T7: "Instructions are just to open up and follow. The service handbook is much of an instruction. But this [a technical-theoretical explanation in a text book] is different. This you have to read to really understand and be able to use in reasoning."

Another example is how the teachers in In $\mathrm{T}$ make a difference between the ways historic recounts of design ideas, tables of wood humidity values, or draughts should be read in order to serve its vocational purposes. The interviewees from CR stress in interviews how ideologies of the author influence the text, but this focus is not observed being recontextualised in teaching. In the teaching in CR, interactive movability is rather shown when a genre is introduced:

T3: "This is a case so now we move into a recount."

In RF the author role is discussed when the teacher asks the students what source they will use to get information:

Student: “The National Food agency is good to read. They're neutral when writing."

Awareness that author perspective and ideology influence texts reveals interactive text movability at VT:

T7: "All texts are a core of fact, then opinions and surrounding that sheer speculation, you need to sort out what is speculation." 
In summary, text movability of all three types, text-based, associative and interactive contribute to texts being talked about in several ways to explore, use, and critique text content, to link text content to earlier knowledge and experience, as well as to objectively consider e.g. genre and text category, or authors' perspectives.

\section{Reading types}

This section presents the results of the analyses of reading types, revealing purposes of reading, why reading is done, both as stated in interviews and revealed in the educational context. The reading types that emerge are efferent, analytical, aim to answer questions, and clarify queries. Texts are carefully read and considered since practical outcomes depend on the understanding of the text. The way reading is discussed indicates factual individually-oriented reading types concerning professional identity, as a skilled pre-school assistant teacher, joiner, welder, chef, or car mechanic:

T7: "Reading is really about identity. What you read is how you can talk to people, as a car mechanic, and being able to talk to customers."

Reading practices are also linked to developing skill:

T7: "We want to be able to understand, to be able to repair. It is not just to use a screwdriver, bang, and change tires. You must understand and be able to explain and you don't learn that in the workshop. To learn that we need to work on reading this."

\section{Analytical-technical reading}

In all four vocational areas analytical-technical reading types are displayed. The interviewees claim to read to learn about concepts, theories, or technical systems. Analyticaltechnical reading is also apparent in the educational contexts. At RF the students are instructed:

T8: "You need to learn more about for instance proteins and so you study."

InVT analytical-technical reading builds knowledge about physics and technology, in CR about children's development.

\section{Analytical-technical-practical reading}

Analytical-technical-practical reading is also displayed in all vocational areas, i.e. texts are studied in order to learn facts that later can be used in practical tasks. In the interview T4 says:

T4: "The text content must end up in the hands. I want to touch the material I read about. Reading is to imagine how to handle things practically.”

In the classroom when teaching about different wood materials, T4 reads aloud, stops to summarise, discusses terms, while at the same time passing around pieces of material. He tells the students: 
T4: "You must understand this text so that you can make good choices when you make your boxes."

Analytical-technical-practical reading is revealed as a stepping stone into craft, cooking, pedagogic work, or repairs.

\section{Analytical-practical reading type}

In InT, VT, and RF some tasks require analytical-practical reading for instance when following a recipe to cook, a draught when welding an object, or a manual to repair a certain fault in a car.

\section{Analytical-assessing reading type}

In the analyses, the analytical-assessing reading type stands out as specific in the four practices.

In $\mathrm{CR}$ the reading type emerges as analytical-assessing ethically regarding lifesituations:

T3: "When you read this I want you to reflect on what would be ethical behavior."

The teacher here instructs the students to apply an analytical-assessing reading type. In a following text-talk aspects in the text are ethically assessed based on what the learning object is.

At InT, this reading type emerges as analytical-assessing aesthetically, i.e. to visualise text content by deconstructing and reconstructing it in creative, aesthetic ways:

T4: "I evaluate the text content regarding designs and suggested materials."

T4 models this reading type with the students:

T4: "Reading this table will help us decide on the best material for both form and function."

At VT, reading is analytical-assessing technically when a text's correctness and workability is assessed e.g. when troubleshooting by following a text.

In $\mathrm{RF}$, the reading type emerges as analytical-assessing gustatory, construing a sense of taste from the text:

T8: "A skill of our trade is to be able to feel, sort of evaluate, tastes when reading."

Reading here entails an analytical-assesing reading type assessing the gustatory implications of the text content.

At both VT and CR, an interesting result is how fiction is read as a way to develop professional competence.

At VT, the class starts every day with 20 minutes of reading of fiction (cf. Visén 2020). The literature is not discussed but considered a tool for developing useful reading skills: 
Student: "We have read so much now and it helps, when you go into the workshop you need to read and when you have read fiction first you are sort of already going."

Several students claim that the reading of fiction increases their reading speed ${ }^{8}$ which they find beneficial in the workshop. The reading of fiction emerges as analyticaltechnical developing vocabulary, reading speed, and general knowledge:

T7: "I develop vocabulary, and things to talk about, how I can talk to customers and people in general, and speed so I quickly can read a lot of text."

However, the purpose of reading fiction is also commented as:

T7: "You want to have something to talk about at the coffee table, something general like."

In $\mathrm{CR}$, the interviewees claim that they develop professional skills through reading fiction which reflects the development of individuals. In teaching contexts at CR, biographies and other narratives are explored, ethically assessing life-situations and concepts of e.g. leadership and psychological development. Thus, efferent ways of approaching fiction are revealed in the two contexts.

In summary, the analyses show reading types closely linked to the practices of the professions. The reading types that were reported in the interviews were also observed in the educational contexts. Reading is done for a number of purposes such as learning: analytical-technical reading type, learning and doing: analytical-technical-practical reading type, doing: analytical-practical reading type, and applied contextually for assessing: analytical-assessing reading type. The assessing reading type is further specified in the different vocational areas involving ethical, aesthetical, technical or gustatory assessment of text content.

\section{Discussion}

The initial comments from vocational teachers asked to partake as informants in the present study were that they don't read much. In Darvin's (2004, 2006) studies vocational instructors also considered their work with texts as tricks of the trade rather than reading. In light of the reading practices revealed in this study such comments do not reflect actual practices, but rather ideas of reading, that do not include what vocational professionals, educators, and students do with texts. Such ideas might stand in the way of explicit reading instruction that could scaffold students' learning and development of specific and situated literacy skills.

The results of this study, thus, both confirm and to some extent further earlier findings (e.g. Darvin, 2004, 2006; Parkinson \& Mackay, 2016). In summary, the

\footnotetext{
${ }^{8}$ Increases in students' reading speed are confirmed by yearly tests conducted by the school's special pedagogue.
} 
results of the present study show that vocational literacy practices depend on a plethora of texts, entail collective reading, pendulum-reading, dynamic text movability, as well as specific reading types. This investigation, as Darvin's (2006), draws from interviews with and observations of informants working as vocational teachers. These informants can be considered literacy experts due to both training and experience in their respective vocations. Consequently, the interviews reveal vocational reading practices, while the observations show how vocational reading literacy practices are acted out in Swedish upper secondary school. The observations are limited to one group each in only four programs. The article, therefore, presents no generalisable claims, but rather give examples of situated vocational disciplinary reading literacies. Nevertheless, these examples can be assumed to resemble conventionalised ways of using text (cf. Hellne-Halvorsen, 2014).

\section{What can the texts that are read tell us about vocational disciplinary literacy?}

When investigating the first research question about what is read the results reveal a variety of texts. The texts in the study range from the general to the specific, from news articles to work instructions and popular science, and are often complex (cf. Buch, 2015, 2020; Danielsson \& Selander, 2014). The plethora of texts indicates that reading has several functions in the vocations. Further, the wide range tells us that functional vocational literacy demands of the reader to comprehend subject content expressed in diverse text categories and genres exploring developments and questions related to the field. The range of texts also indicates how disciplinary texts are distributed within the triangle between academy, workplace, and society (cf. Airey, 2011). One example is how T7 as a car mechanic reads academic text to understand the science of steering systems, service handbooks for repair instructions in the workshop, and debate articles about self-driving cars, claiming that he needs all to function with authority in his field.

\section{What can the reading events and text movability tell us about vocational disciplinary literacy?}

To answer the second research question about how reading is done and talked about, two analytical tools were used, reading literacy events and text movability. The study shows situated ways of reading that form and are formed by the specific contexts (cf. Barton, 2007). The reading literacy events, including skimming to search information, careful linear reading, as well as collective reading which builds shared knowledge, are both similar to and diverge from more academic literacies. Regarding the authority of the texts, historians consider author's perspective, while chemists consider how recent the text is (Shanahan \& Shanahan, 2008). This article shows how the experts from CR, RF, and VT approach texts critically considering authorial voice in order to assess reliability, while reading critically in $\mathrm{InT}$, RF, and VT also 
means examining correctness and workability. Assessment of content and authorial perspective in the use of parallel texts in different categories indicate informed and multifaceted critical reading (cf. Hicks \& Steffel, 2012). At the same time, deconstructive ways of reading indicate reading as creative and three-dimensional processes building understanding for process and product.

The present study also shows the use of pendulum-reading, a pendular movability between text and task, as a central aspect of vocational literacy practices. Pendulum-reading is an intrinsic part of work practice and indicates an interrelationship between text-interpretation and hands-on work. Pendulum-reading may be compared to how chemists go back and forth between different representations (Shanahan \& Shanahan, 2008). However, the transaction that takes place in vocational pendulum-reading is one where the understanding of the text content materialises in process and product.

The text movability (Hallesson \& Visén, 2018; Liberg et al., 2012; Visén, 2015), which is of all three types and in several dimensions, indicates how knowledge is built through reading. Text content is explored in text-based dimensions, as vocabulary, by summarising, as well as by generalising and critically examining whether content will lead the reader correctly in the work process. Thereby readers are: "taking an informed and multifaceted stance in relation to the text" (cf. Hicks \& Steffel, 2012 , p. 129). Text content is also explored associatively, synthesising it with previous knowledge and experience from the workplace. Interactive movability discussing author's perspective, genre, and text category emerges as crucial e.g. in the ability to find reliable texts and to apply functional ways of reading. The automotive technology interviewees e.g. stress how a car mechanic needs to be a critical reader of debate articles and branch journals concerning new technology, and therefore read research and technical and physics literature to gain knowledge that can help see through opinion. Dynamic text movability through talking about texts in many ways is thus also an aspect of vocational literacy.

\section{What can the reading types tell us about vocational disciplinary literacy?}

The third research question about what purposes the reading fulfills is answered through analysing reading types. Darvin (2006) means that vocational educators read to solve problems, and Lindberg (2010) shows how vocational students read to accomplish tasks. In this study, the informants also talked about analytical-practical reading 'to do'. But, in addition to that, the results indicate a wider range of reading types. Much reading was described as building a bank of general knowledge within the field. Reading had both efferent and aesthetic aspects, as in InT when an aesthetically assessing reading type was applied. However, none of the reading types were fully aesthetic meeting the text as a work of art in itself (cf. Rosenblatt, 1995). All reading types originated in efferent ways of reading, were factual (cf. Josephson \& Melander, 2003), analytically searching for certain answers in the text. Nonetheless, the reading types 
were both text-oriented, grappling with the text as such, and individually-oriented (cf. Josephson \& Melander, 2003), functioning to develop a professional identity.

Since analytical-assessing reading types can be specific in different practices and closely related to vocational purposes e.g assess forms and functions in a text in carpentry or tastes in cooking, it may pose a challenge to students, and teachers may, therefore, need to be more explicit.

The reading types that emerge in this study thus add to show the complexity and situatedness of vocational literacy.

\section{Conclusions}

To conclude, reading is a crucial and specialised aspect of vocational practice and of vocational education, and the reading literacy practices are complex. These reading practices require informed and critical readers, rather than the presumed uncritical vocational model readers e.g. Swedish subject text-books construct (cf. Lilja Waltå, 2016). Therefore it may be in place to challenge limiting ideas of texts, reading and readers in vocational education and contexts.

Furthermore, in the light of the complex literacies that emerge in the present study, it can be argued that vocational teachers need to teach the specific literacies. The disciplinary vocational literacies revealed in the present study are to varying extents made explicit to students. This might be due to the vocational teachers not having been given tools to teach e.g. pendulum-reading, dynamic ways of talking about texts, or critical reading. Also, in the educational contexts students are socialised into somewhat limited versions of the vocational disciplinary reading literacies the interviewees describe. This may be a necessary pedagogic recontextualisation of content and activity. At the same time it might be problematic, for instance if vocational students experiencing difficulties reading texts in the workplace-based learning tend to make use of school strategies like asking for help rather than independent strategies for reading (cf. Olofsson, 2011). That students are able to flexibly enter what Karlsson (2009) calls literacy roles and thus participate actively and functionally in different literacy events may be key both to successful problem-solving and to learning. Vocational disciplinary literacy teaching therefore should encompass ways of reading employed by expert readers (cf. Shanahan \& Shanahan, 2008).

Having said that, for teaching to fully encompass vocational disciplinary reading literacy practices more knowledge is required. This study gives an overview of some aspects of the complexity of vocational reading literacies and vocational disciplinary reading literacies in school contexts. Nevertheless, questions remain. Disciplinary literacies in vocational education need to be further researched, and in more detail, e.g. literacy aspects of the variety of subjects, as well as multimodal and multilingual aspects noted in this study remain to be studied. Also, closer case-studies of how reading literacy practices may be specific to the different vocational programmes would contribute both to vocational education as well as to the field of disciplinary literacy. 


\section{P. Visén}

\section{Author biography}

Pia Visén, $\mathrm{PhD}$, holds a position as senior lecturer at the department for language education at Stockholm University. Her research interests include disciplinary literacy, text talks, reading, and upper secondary school vocational literacies. She is currently part of a four year research project funded by the Swedish Research Council, "Läsmetoder under lupp". The main aim of the project is to provide tools to illuminate how different approaches to working with texts in various school subjects create different conditions for students' disciplinary reading literacy and literacy development.

\section{References}

Airey, J. (2011). The disciplinary literacy discussion matrix: A heuristic tool for initiating collaboration in higher education. Across the Disciplines, 8(3), 1-9. https://doi.org/10.37514/ATD-J.2011.8.3.18

Barton, D. (2007). Literacy: An introduction to the ecology of written language. (2. ed.) Blackwell.

Buch, B. (2015). Tekster og genrer på erhvervsuddånnelserne - med scerligt henblik på overgången frå grundskole til erhvervsuddånnelse. [Diss.]. Aarhus University.

Buch, B. (2020). Using SFL as a powerful tool for analyzing multimodal texts from vocational education. Globe: A fournal of Language, Culture and Communication, 10, 67-81.

Danielsson, K., \& Selander, S. (2014). Se texten!: Multimodala texter i ämnesdidaktiskt arbete. (1. ed.) Gleerup.

Darvin, J. (2004). Are we being taught to punch the clock? Politics and situated literacy in one vocational high school. [Diss.] Hofstra university Hempsted.

Darvin, J. (2006). "On reading recipes and racing forms": The literacy practices and perceptions of vocational educators. Fournal of Adolescent $\mathcal{F}$ Adult Literacy, 50(1), 10-18. https://doi.org/10.1598/JAAL.50.1.2

Hallesson, Y., \& Visén, P. (2018). Intertextual content analysis: An approach for analysing text-related discussions with regard to movability in reading and how text content is handled. International fournal of Research \& Method in Education, 41(2), 142-155. https://doi.org/10.1080/1743727X.2016.1219981

Halliday, M. A. K. (2014). Halliday's introduction to functional grammar. (4. ed.). Routledge.

Hellne-Halvorsen, E. B. H. (2014). Skrivepraksiser i yrkesfaglige utdanningsprogrammer. [Diss.] University of Oslo.

Hicks, T., \& Steffel, S. (2012). Learning with text in English language arts. In T. L. Jetton \& C. Shanahan (Eds.), Adolescent literacy in the academic disciplines: general principles and practical strategies (pp. 120-153). The Guilford Press.

Hållsten, S. (2008). Ingenjörer skriver: Verksamheter och texter $i$ arbete och utbildning. [Diss.] Stockholm University. Ivanic, R., Edwards, R., Barton, D., Martin-Jones, M., Fowler, Z., Hughes, B., Manion, G., Miller, K., Satchwell, C., \& Smith, J. (2009). Improving learning in college: Rethinking literacies across the curriculum. Routledge.

Janks, H. (2010). Literacy and power. Routledge.

Josephson, O., \& Melander, B. (2003). Läsare och läsarter. In B. Englund \& P. Ledin. (Eds.), Teoretiska perspektiv på sakprosa. Studentlitteratur.

Kabel, K. Gissel, S. T., \& Carlsen, D. (2009). Lesbare leremidler. EUD. Læremiddel.dk \& Nationalt Videncenter for Læsning.

Kakela, J. (1993). The vocational interactive reading project: Working with content area specialists. Fournal of Reading, 36(5), 390-396.

Karlsson, A-M. (2009). Positioned by reading and writing literacy practices, roles, and genres in common occupations. Written Communication, 26(1), 53-76. https://doi.org/10.1177/0741088308327445

Karlsson, A-M. (2012). En arbetsdag $i$ skriftsamhället: Ett etnografiskt perspektiv på skriftanvändning $i$ vanliga yrken. (2. ed.) Språkrådet.

Liberg, C., af Geijerstam, Å., Folkeryd, J. W., Bremholm, J., Hallesson,Y., \& Holtz, B. M. (2012). Textrörlighet ett begrepp i rörelse. In S. Matre \& A. Skaftun. (Eds.), Skriv! Les! 1. Artikler fra den første nordiske konferansen om skriving, lesing og literacy (pp. 65-80). Akademika forlag.

Lillis, T. (2008). Ethnography as method, methodology, and "Deep Theorizing". Closing the gap between text and context in academic writing. Written Communication, 25(3), (pp. 353-387). https://doi.org/ $10.1177 / 0741088308319229$ 
Lindberg, V. (2010). Learning practices in vocational education. Scandinavian fournal of Educational Research, 47(2), 157-179. https://doi.org/10.1080/00313830308611

Lilja Waltå, K. (2016). "Äger du en skruvmejsel?” Litteraturstudiets roll $i$ läromedel för gymnasiets yrkesinriktade program under Lpf 94 och Gy 2011. [Diss.]. Göteborgs universitet.

Martin, J. R., \& Rose, D. (2008). Genre relations: Mapping culture. Equinox.

Moje, E. B. (2007). Developing socially just subject-matter instruction - A review of the literature on Disciplinary Literacy. Review of Research in Education, 31(1), 1-44. https://doi.org/10.3102/0091732X07300046

Moje, E. (2008). Foregrounding the disciplines in secondary literacy teaching and learning: A call for change. Fournal of Adolescent $\mathcal{E}$ Adult Literacy, 52(2), 96-107.

Olofsson, H. (2011). Skriftbruk i fordonsverkstaden: en studie av läs-och skrivstrategier $i$ mötet med arbetslivets texter [Lic.] Stockholms universitet.

Parkinson, J., \& Mackay, J. (2016). The literacy practices of vocational training in Carpentry and Automotive Technology. Fournal of Vocational Education E Training, 68(1), 33-50. https://doi.org/10.1080/13636820. 2015.1104714

Rose, D., \& Martin, J. R. (2012). Learning to write, reading to learn. Genre, knowledge and pedagogy in the Sydney school. Equinox.

Rosenblatt, L. M. (1995). Literature as exploration. (5. ed.) Modern Language Association of America.

Schleppegrell, M. J. (2004). The language of schooling: A functional linguistics perspective. Lawrence Erlbaum.

Schwenger, B. (2018). Research on training wheels - embedding academic literacy and numeracy in vocational pedagogy through action research. Educational Action Research, 26(2), 288-300. https://doi.org/10.1080/ 09650792.2017 .1310053

Shanahan, T., \& Shanahan, C. (2008). Teaching disciplinary literacy to adolescents. Harvard Educational Review, 78(1), 40-59. https://doi.org/10.17763/haer.78.1.v62444321p602101

Shanahan, T., \& Shanahan, C. (2012). What is disciplinary literacy and why does it matter? Topics in Language Disorders, 32(1), 7-18. https://doi.org/10.1097/TLD.0b013e318244557a

Skolinspektionen [Swedish Schools Inspectorate]. (2013). Fördjupad tillsyn på yrkesprogram. Rapport över fördjupat tema i tillsynen. Skolinspektionen.

Skolverket [National Agency for Education]. (2020). Skolverkets statistik. https://www.skolverket.se/skolutveckling/ statistik/arkiverade-statistiknyheter/statistik/2019-10-29-statistik-om-sokande-till-gymnasieskolan-2019-20

Swedish Research Council [Vetenskapsrådet]. (2017). Good research practice. Vetenskapsrådet.

Säljö, R. (2010). Lärande i praktiken: Ett sociokulturellt perspektiv. (2. ed.) Norstedts.

Tengberg, M. (2011). Samtalets möjligheter: Om litteratursamtal och litteraturreception $i$ skolan. [Diss]. Göteborgs universitet.

Westman, M. (2009). Skriftpraktiker i gymnasieskolan: Bygg- och omvårdnadselever skriver. [Diss.] Stockholms universitet.

Visén, P. (2015). Att samtala om texter: Från träteknik och svetsteori till antikens myter: Textsamtalets möjligheter som närmaste zon för läsutveckling i en klass på gymnasiets industritekniska program. [Diss.] Stockholms universitet.

Visén, P. (2020). Läspraktiker i en fordonsklass på gymnasiet. In M. Johansson, \& B.-G. Martinsson (Ed.), Trettonde nationella konferensen $i$ svenska med didaktisk inriktning Bildning, utbildning, fortbildning. Linköping 22-23 november 2018. Linköpings universitet. Nationella nätverket för svenska med didaktisk inriktning. 